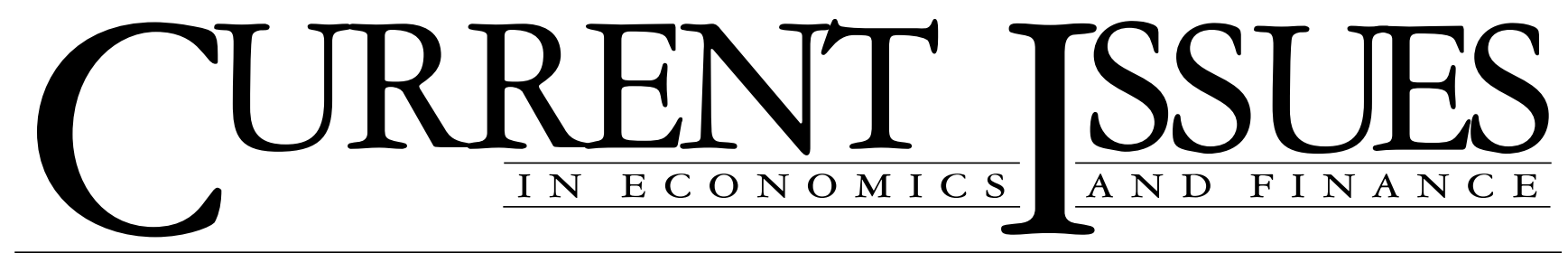

February 1996

Volume 2 Number 2

\title{
Dynamics of the Second District Economy
}

\author{
Jason Bram
}

\section{Consumers and analysts remain wary about the economic prospects of the Second District. But is caution here simply becoming habit? True, there are some weak spots, but strong performance in the southern tier is pointing to a brighter economic future for the district.}

A mood of pessimism prevails in the Second District of the United States-New York State, northern New Jersey, and southwestern Connecticut ${ }^{1}$ - even as the region's recovery from the 1989-92 recession continues. In late 1995, consumer confidence still languished at recessionary levels while it was high in other parts of the country $^{2}$ (Conference Board 1996). Consumers' apprehension is not surprising: the region's economic performance has lagged the nation's since 1989 (Steindel and Banks 1994). The district's 1989-92 recession brought the worst job losses since the 1930s, and only a fraction of the jobs have been recovered.

Will developments in the second half of the decade reinforce this chronic pessimism? Fortunately, in the southern part of the district (the New York City area), which represents three-quarters of the district's entire economy, signs of progress are emerging. Although certain sectors continue to downsize, the forces behind the early-1990s slump have largely dissipated and the business climate has improved. This downstate strength is countering the dreary performance of the district's northern sections, where restructuring continues in local industries and job growth has virtually ground to a halt.

This edition of Current Issues reviews the key structural, or region-specific, factors that contributed to the Second District's 1989-92 recession and identifies the major forces that will determine how the economy will fare in 1996 and beyond. A detailed examination of employment trends reveals why the district's fortunes are divided: the New York City area's industry mix, inflation trends, and other attributes are helping to turn its economy around, while downsizing in manufacturing and state government is restraining economic growth in the northern part of the district.

\section{Assessing Regional Performance}

To isolate the dynamics of the Second District's economy, we compare the region's performance to that of the nation. Our measures are income and employment, the most widely used proxies for quarterly economic growth at the regional level. Although income is a more comprehensive measure of economic activity, employment data offer a better tool for current analysis: they are released with only a one-month lag (as compared to six months for income) and are available by both state and metropolitan area (as compared to state only for income).

Over the past eight years, income growth in New York, New Jersey, and Connecticut has been close to the national average (Chart 1). As of 1993, these three states still led the nation in per capita income. Between 1989 and 1993, total personal income grew at a 4.3 percent average annual rate, a rate not substantially different 
from the 5.2 percent pace of growth for the nation as a whole. Although a bad year on Wall Street depressed the region's income growth relative to the nation's in 1994 and early 1995, a bull market in 1995 boosted Wall Street profits and should generate a strong rebound in regional income in 1996.

In general, employment trends in the early 1990s were more dismal than income trends, although they were not as dismal as they appear (see box). To capture the range of local trends, we look at employment data ${ }^{3}$ for the district's five economic regions (see map). As defined by the Bureau of Economic Analysis, an economic region is a grouping of cities and counties with interdependent economies based on urban hubs and commuting patterns. ${ }^{4}$

\section{Employment Trends: New York City Economic Region}

The entire southern tier of the district ${ }^{5}$ (New York City, Long Island, northern New Jersey, southwestern Connecticut, and the lower Hudson Valley) represents one economic area. This affluent, densely populated area accounts for about 75 percent of the district's economy. Its own economy is largely service-based and depends heavily on the financial industry. New York City is clearly the hub, with suburban commuters holding one-fifth of all jobs. ${ }^{6}$ However, key manufacturing industries in outlying areas also serve as engines of local income and job growth: defense (Long Island), chemicals and pharmaceuticals (New Jersey), and office equipment (Hudson Valley).

Relative to the national economy, the New York City area economy turned in a strong performance in 1995, in contrast to the previous six years when it was among the weakest in the nation (Chart 2). The major causes

\section{Chart 1 \\ Personal Income Growth: Tri-state Region and the United States}

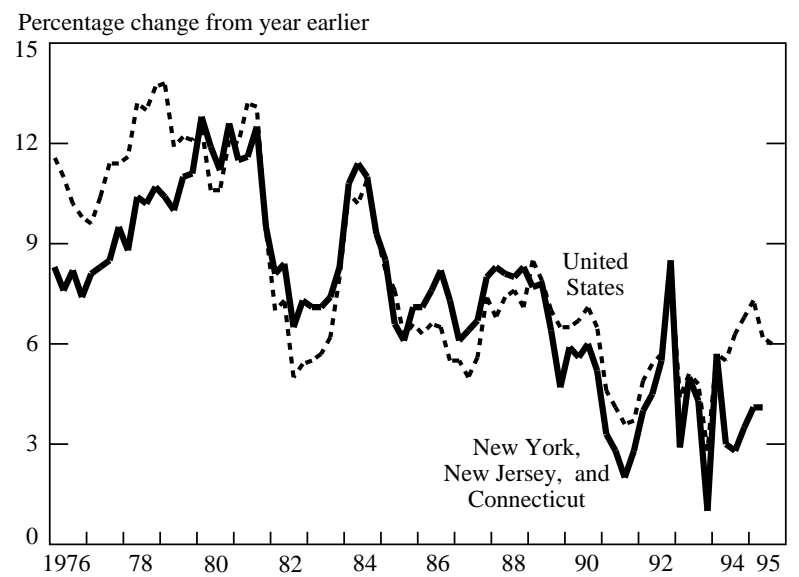

Source: U.S. Bureau of Economic Analysis. of the area's lagging performance in 1988-94 were a downturn on Wall Street, a bursting of the real estate bubble, an exodus of manufacturing industries, and a high cost structure.

In 1995, however, the local economy showed resilience, with job growth holding a steady pace despite the national slowdown and sharp job cuts in New York State and City governments. From the fourth quarter of 1994 to the end of 1995, local area employment grew by 1.2 percent in the private sector and by 0.8 percent overall, matching 1994's growth. This growth rate is less than a point below the national rate-the narrowest gap since 1987 and a sign of underlying strength in the local economy. Moreover, the improvement was seen in a variety of industries, ranging from securities to manufacturing.

Key Industry Trends. Many of the region-specific problems and imbalances that developed during the 1980s have diminished. New York City's manufacturing sector is no longer a significant drag on growth, a development that augurs well for the area's economic prospects. The city's manufacturing job base, which shrunk at a 4 percent annual pace over the past decade, stabilized in 1995. Job losses, at less than 1 percent, were the mildest since 1983 - an impressive feat, given last year's downturn in U.S. manufacturing employment.

In the lower Hudson Valley, manufacturing employment has stabilized over the past two years, after being hit hard by IBM's restructuring in 1992-93. In addition,

\section{Chart 2 \\ Job Growth: New York City Region and the United States}

Percentage change from year earlier

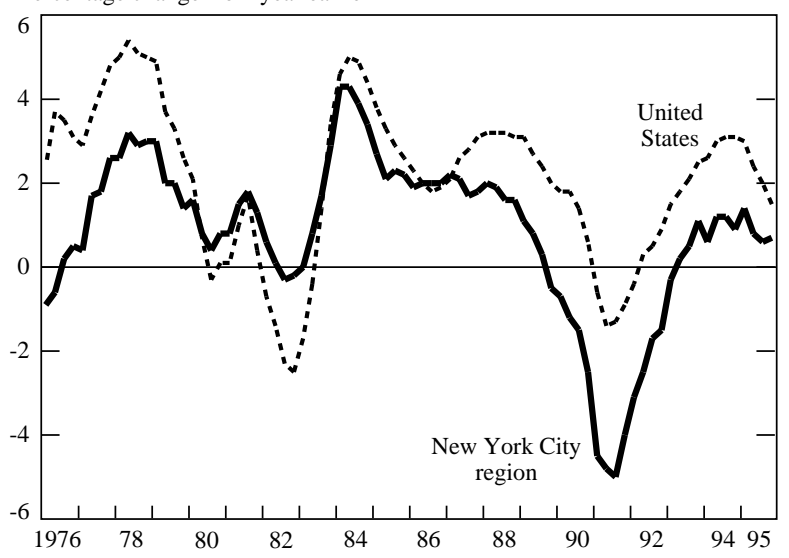

Sources: U.S. Department of Labor, Bureau of Labor Statistics; New York State, New Jersey, and Connecticut Departments of Labor.

Note: For 1988, a distortion in the data for growth rates occurs because in that year the government redefined some metropolitan areas in the New York City region. To eliminate this distortion, we ran a regression to determine the historical relationship between growth in the redefined areas and growth in unaffected areas. 


\section{Economic Regions of the Second District}

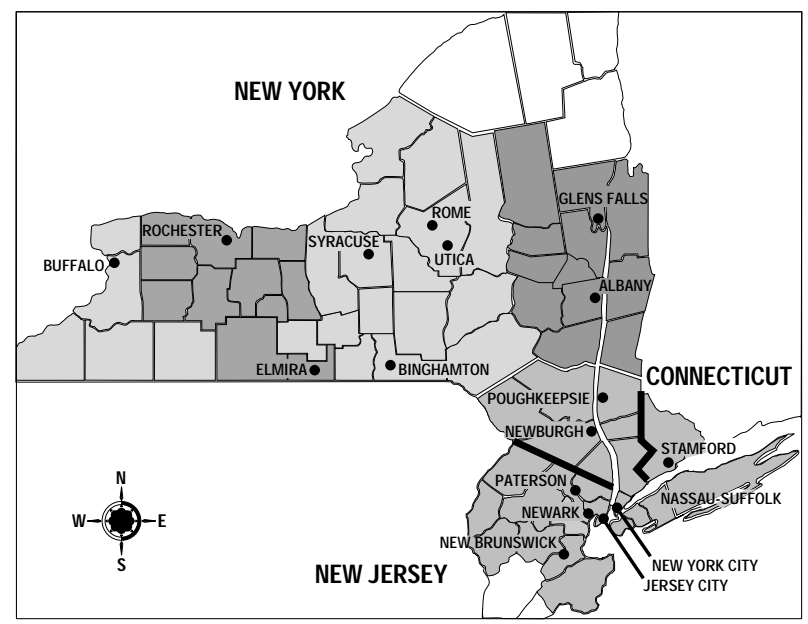

vacated research and development facilities and the area's pool of skilled labor have attracted a cluster of high-tech start-up manufacturing firms to the Dutchess County area (Hammonds and Sager 1995).

In addition, technological advances are giving rise to an industry cluster loosely called new media, centered in New York City. ${ }^{7}$ This grouping cuts across a number of the city's traditional industries (for example, publishing, advertising, motion pictures, educational services), which thrive on the region's well-educated work force. Growth at small high-tech firms should help offset at least some of the effects of restructuring at AT\&T, which plans to eliminate approximately 7,000 jobs in New Jersey.

Despite consolidation in the commercial banking industry, the region's higher-paying securities industry has been creating jobs steadily, though at a more modest rate than in the 1980s. After the 1987 stock market crash, job and income losses on Wall Street played a major role in this area's 1989-92 economic downturn. In addition to the crash's direct effects, it caused severe ripples in local real estate markets and retailing and eroded the tax base. Employment in this sector began to recover in 1992, but growth stalled in mid-1994 as a result of turbulence in the financial markets. However, last year's bull market on Wall Street should generate more job gains and boost year-end bonus payments-factors that should energize the local economy and help the area's tax base in $1996 .{ }^{8}$

Real estate and construction, which also figured importantly in the area's last downturn, are stronger than they have been in many years. A paucity of building in the early 1990s has whittled down the glut in both the commercial and residential markets and has sparked a moderate recovery in real estate jobs and a stabilization in construction jobs. Home prices remain flat, but sales volume has picked up.

The area is also drawing out-of-towners. Tourism, a key local export sector, flourished in 1994 and 1995, buoyed by a weak dollar and stronger economies in the Northeast and overseas (Bram 1995).

However, the outlook for this region is not entirely positive. A few important industries are likely to be a drag on the economy in the year ahead. For example, declining employment in northern New Jersey's manufacturing sector has paralleled the national downturn in this sector, and Long Island's defense industry continues to lose jobs at a rapid pace. Health care-one of the few industries to add jobs throughout the region's recessionmay be poised for substantial downsizing (Lowenstein 1995). In addition, consolidation in both commercial banking and government has already translated into sharp job losses, which show few signs of letting up.

On balance, however, employment losses in shrinking sectors should at least be offset by job growth in emerging industries and by gains resulting from improvement in the general business climate-including reduced inflation and increased cost competitiveness.

\section{Understanding the Employment Gap between the Second District and the Nation}

Job growth in the Second District has almost always lagged national job growth, although the district's growth rate approaches the U.S. rate during regional economic booms (Chart 2).

Over the past twenty years, the region's job growth has averaged more than a full percentage point below the nation's. This gap was more than 2 points in the late $1970 \mathrm{~s}$; it fell to 0.5 points during the $1980 \mathrm{~s}$ boom. But it jumped to 2.5 points during the region's 198992 recession as sharp job losses coincided with slight gains at the national level. In the first two years of recovery (1993-94), job growth still trailed the national average by 1.9 points. In 1995 , however, the gap narrowed to 1 point, close to its historical norm.

This job growth gap persists because the Second District is a mature region, which means that the long-run potential or "natural" growth rate of both the economy and the population is significantly lower than the nation's. A mature region can be compared to a developed country with a well-established industrial base and infrastructure, high per capita income, and slow population growth. 
A Better Business Environment. One of the New York City area's greatest assets is a skilled work force, which tends to attract growth industries. The region's industry mix also bodes well for job trends: sectors that are projected to grow rapidly in the years ahead tend to have an above-average presence in this metropolitan region.

Moreover, regional inflation trends have turned favorable. Persistently above-average inflation during the 1980s weakened the area's competitive position (Rosen and Wenninger 1994). As a result, a number of large businesses moved their headquarters outside the region during the 1980s, and many others shifted back-office operations to less expensive areas. But inflation has remained close to or below the national rate for two years, and home prices have moved much closer to the U.S. average since 1987 (Charts 3 and 4). These forces are helping to make the region more affordable for potential residents and more competitive for businesses. ${ }^{9}$

\section{Employment Trends: Upstate New York}

In contrast to the New York City area, the other economic regions of the Second District have performed sluggishly. Industry mix may account for some of this weakness. The four smaller regions that constitute upstate New York are more rural, less affluent, and have a much lower cost structure than their downstate counterpart. They also tend to have a higher concentration of manufacturing industries and are not much affected by Wall Street's ups and downs (except through the conduit of state fiscal problems).

Although upstate New York's job losses were only slightly more severe than the nation's during the early 1990 s (Chart 5), this area has been the weaker segment of the

\section{Chart 3}

Inflation in the New York City Region and the United States

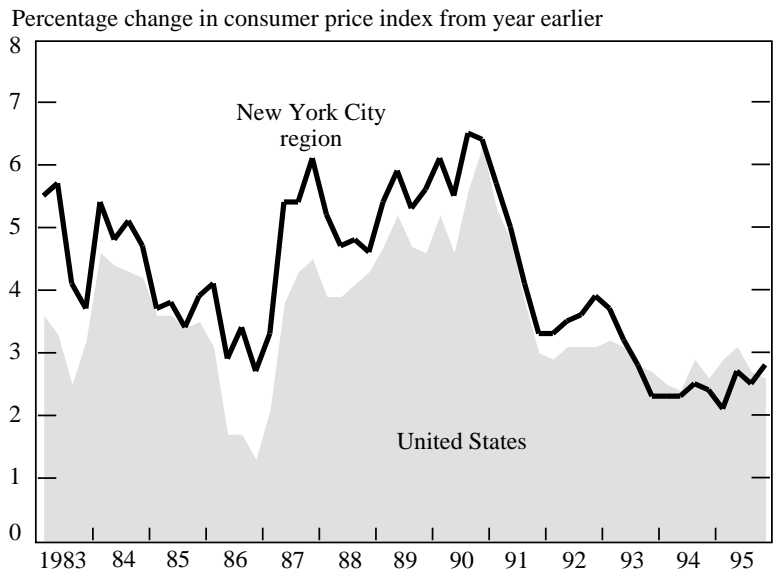

Source: U.S. Department of Labor, Bureau of Labor Statistics.
Second District since 1993. In 1994, job growth in the area failed to accelerate in tandem with that of the nation. In 1995 , growth slowed more sharply than for the nation overall, and a number of localities experienced outright declines.

Specifically, heavily industrial areas such as Buffalo and Rochester were impaired by last year's nationwide downturn in manufacturing employment. At the same time, the Albany area was hit by cuts in state government. Even within specific industries (especially manufacturing), most of these areas are falling well behind the nation in growth, a gap that points to more persistent structural problems. A brief overview of each of the four economic regions highlights the factors that are contributing to subpar performance.

Albany Region. Job growth in the Albany area, which had been among the strongest in the district, slowed sharply in early 1995 and turned down by year end as a result of layoffs in state government - the key local industry. Overall, fourth quarter 1995 employment was down 0.6 percent from a year earlier, compared with 1.2 percent growth in 1994. Employment in state government, which had grown by 1.7 percent in 1994, fell by more than 7 percent in 1995. Private sector employment continued to grow in 1995, but at a much slower pace. Job losses intensified in durable goods manufacturing, while employment growth slowed in construction, finance, insurance, real estate, and retailing.

The Albany area is the only economic region in the Second District where private sector employment had recovered beyond its pre-recession peak. But government layoffs are clearly beginning to have a ripple effect on local-market industries such as retailing and construction. As of third quarter 1995, home prices had already fallen

\section{Chart 4 \\ Median Home Prices: The New York City Region's Premium}

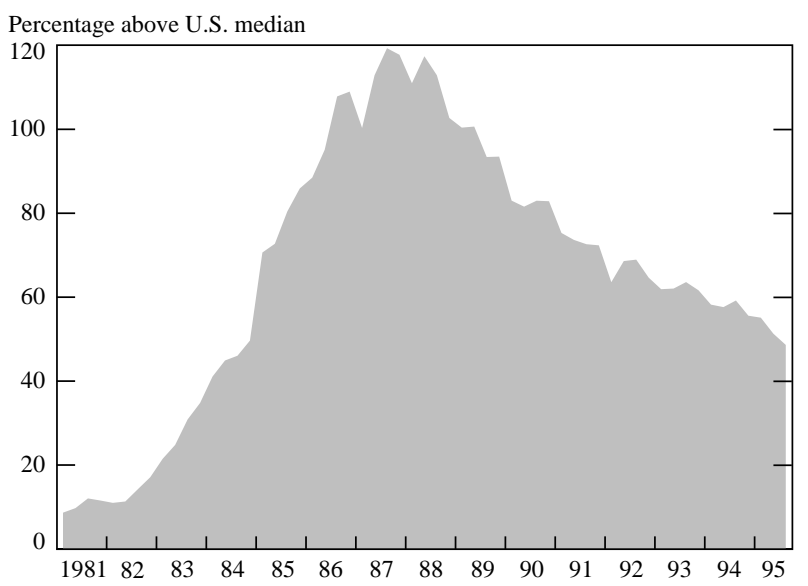

Source: National Association of Realtors. 
by more than 5 percent from a year earlier-the biggest decline since records were first established in 1980.

Syracuse Region. Local job growth in the Syracuse area has halted. By the end of 1995, employment was flat compared to a year ago, with declines in metropolitan Syracuse and Binghamton offsetting gains in the UticaRome area. Syracuse, despite its fairly diversified industry mix, has experienced an across-the-board slowdown in manufacturing, retailing, local government, and construction. Moreover, home prices have declined steadily for the past two years, and year-to-date housing permits are running more than 60 percent below 1994 levels.

In Utica-Rome, job growth has slowed from 1994's rapid pace, mostly as a result of the closing of the Rome air force base, which cost the area 1,000 federal government jobs during 1995. Still, private employment has more than picked up the slack. But Binghamton's economy continues to stagnate, bogged down by the area's high concentration of defense manufacturers and restructuring at IBM, the area's largest employer.

Rochester Region. The Rochester area has one of the poorest recent records of job creation in the Second District. In fourth quarter 1995, employment was down 0.4 percent from a year earlier, after growing by a scant 0.3 percent in 1994. Evidently, corporate restructuring accounts for much of the local job market's recent weakness. The largest job cuts were in durable goods manufacturing, which is dominated by Eastman Kodak and Xerox.

However, a number of other industries also show net

\section{Chart 5}

Job Growth: Upstate New York and the United States

Percentage change from year earlier

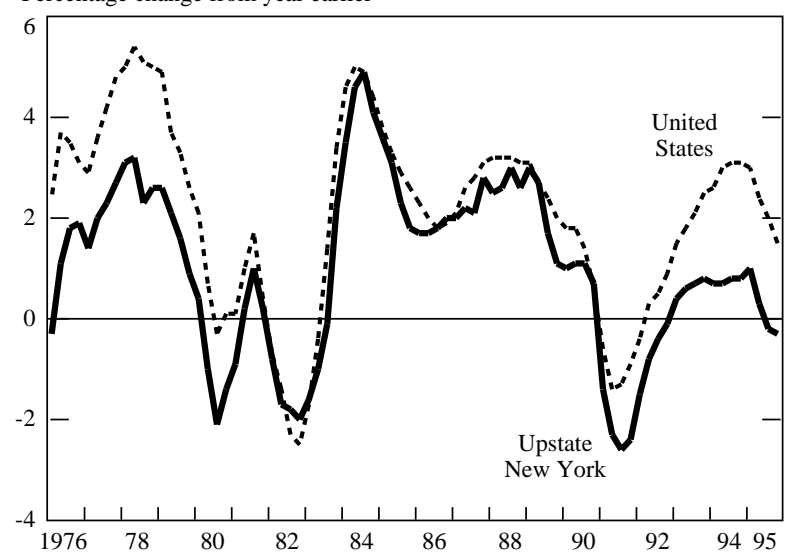

Sources: U.S. Department of Labor, Bureau of Labor Statistics; New York State Department of Labor.

Note: For 1988, a distortion in the data for growth occurs because in that year the government redefined some metropolitan areas in upstate New York. To eliminate this distortion, we ran a regression to determine the historical relationship between growth in the redefined areas and growth in unaffected areas. job losses over the past year including construction, state government, and finance, insurance, and real estate. Despite the recent economic slowdown, local home prices have held up and unemployment rates are lower than a year ago.

Buffalo Region. The Buffalo region has also become one of the district's laggards. After growing by nearly 1 percent in 1994, employment dipped 0.1 percent below year-ago levels in the fourth quarter of 1995. The slowdown has been broad-based, with most major industries registering either a slowdown or outright downturn in employment. One reason may be ongoing weakness in the Canadian economy and Canadian dollar: because trade with Canada is a major component of the local economy, this weakness may be acting as a drag on employment in retailing and transportation. Interestingly, local job growth has picked up in durable goods manufacturing, a crucial local industry, in spite of weakness at the national level.

\section{Conclusion}

The New York City area appears to be making headway against many of the problems underlying the region's chronic economic slump. Inflation has fallen below the national average, housing has become more affordable, and the key securities industry is growing. More generally, the region has a high concentration of future growth industries and a well-educated labor force. An important sign of structural improvement is the region's job growth, which has held up despite a national slowdown and substantial downsizing in state and local government.

The healthy performance of the New York City area contrasts with less favorable trends in northern New York. A number of major upstate corporations are downsizing, and most metropolitan areas registered job losses and declining property values in 1995. Although these developments may, in part, reflect a high exposure to cyclical industries, upstate New York's already sluggish performance in 1994-when the U.S. economy was booming-suggests a prolonged period of weakness. Still, given the dominance of the southern economic region, the outlook for the Second District as a whole is fairly positive.

\section{Notes}

1. Specifically, the district includes New Jersey's Hudson, Bergen, Passaic, Essex, Union, Morris, Warren, Sussex, Middlesex, Somerset, Hunterdon, and Monmouth counties; Connecticut's Fairfield County; and all of New York State. Employment data used in this article also include New Jersey's Ocean County.

2. Regional consumer confidence covers the Middle Atlantic states: New York, New Jersey, and Pennsylvania. In terms of income, approximately 70 percent of that region is in the Second District. 
3. All employment data cited in this article are from the monthly survey of nonfarm business establishments not from the household survey, which is used to derive unemployment rates.

4. In this report, the metropolitan areas cited in each economic region account for the lion's share of that region's economy. Data do not cover rural counties within each region; these counties (some outside the Second District) represent a small fraction of regional economic activity.

5. This region comprises the New York City, Nassau-Suffolk, Newark, Jersey City, Bergen-Passaic, Middlesex-SomersetHunterdon, Monmouth-Ocean, Stamford, Newburgh, and Dutchess metropolitan areas.

6. This figure is derived from the Department of City Planning, City of New York, 1990 Census of Population.

7. "New Media Firms Promise Entry Level Positions," Crain's New York Business, September 25, 1995; "Hot Growth Sectors Will Boost City by Winter,' Crain's New York Business, June 19, 1995; "New Yorkers \& Co.: The Buzz in Silicon Alley," New York Times, September 10, 1995.

8 . The securities industry plays a major role in the city's business cycle because Wall Street salaries average roughly three times New York City's average.
9. Although inflation (as measured by the consumer price index) is not necessarily reflective of business costs, its slowdown concurrent with a recovery in demand strongly suggests that supply-side factors such as cost reductions are also at work.

\section{References}

Bram, Jason. 1995. "Tourism and New York City's Economy." Federal Reserve Bank of New York Current Issues in Economics and Finance 1, no. 7 (October).

Conference Board. 1996. The Consumer Confidence Survey, January.

Hammonds, Keith, and Ira Sager. 1995. "The Town IBM Left Behind.” Business Week, September 11, 1995.

Lowenstein, Ronnie. 1995. "The Health Sector's Role in New York's Regional Economy." Federal Reserve Bank of New York Current Issues in Economics and Finance 1, no. 5 (August).

Rosen, Rae, and John Wenninger. 1994. "Second District Update: A Moderate Recovery Is in Progress." Federal Reserve Bank of New York Quarterly Review 19, no. 1 (Spring).

Steindel, Charles, and Lois Banks. 1994. "Regional Employment Trends in the Second District." Federal Reserve Bank of New York Quarterly Review 19, no. 2 (Summer-Fall).

\section{About the Author}

Jason Bram is an economist in the Domestic Research Function of the Research and Market Analysis Group.

The views expressed in this article are those of the author and do not necessarily reflect the position of the Federal Reserve Bank of New York or the Federal Reserve System.

Readers interested in obtaining copies of Current Issues in Economics and Finance through the Internet can visit our site on the World Wide Web (http://www.ny.frb.org). From the Bank's research publications page, you can view, download, and print any edition in the Current Issues series, as well as articles from the Economic Policy Review. You can also view abstracts for Staff Reports and Research Papers and order the full-length, hard-copy versions of them via e-mail.

Current Issues in Economics and Finance is published by the Research and Market Analysis Group of the Federal Reserve Bank of New York. Dorothy Meadow Sobol is the editor.

Editorial Staff: Valerie LaPorte, Mike De Mott, Elizabeth Miranda

Production: Graphics and Publications Staff

Subscriptions to Current Issues are free. Write to the Public Information Department, Federal Reserve Bank of New York, 33 Liberty Street, New York, N.Y. 10045-0001, or call 212-720-6134. Back issues are also available. 